\title{
フラックス法によるウイレマイト単結晶の成長
}

\author{
瀬戸口正宏・坂本千秋 \\ （大阪工業技術試験所）
}

\section{Crystal Growth of Willemite by Flux Method}

\author{
By \\ Masahiro SETOGUCHI and Chiaki SAKAMOTO \\ (Government Industrial Research Institute, Osaka)
}

\begin{abstract}
Single crystals of willemite have been grown by the slow cooling flux merhod using $\mathrm{Na}_{2} \mathrm{MoO}_{4}$ and $\mathrm{Na}_{2} \mathrm{WO}_{4}$ as solvents. The main experiments on crystal growth were carried out at soaking temperatures of $1215-1405^{\circ} \mathrm{C}$ and cooling rates of $3.3-5.7^{\circ} \mathrm{C} / \mathrm{h}$ with $\mathrm{Na}_{2} \mathrm{MoO}_{4}$ flux which was the most promising flux, and mixtures of $\mathrm{ZnO}$ and $\mathrm{SiO}_{2}$ with molar ratio of $2: 1$ and $\mathrm{Zn}_{2} \mathrm{SiO}_{4}$ powders prepared by solid-state reaction at $1400^{\circ} \mathrm{C}$ were used as starting materials. The needle-shaped willemite crystals as large as $0.36 \mathrm{~mm}$ in diameter and $6.0 \mathrm{~mm}$ long were grown from spontaneous nuclei on a wall of a Pt crucible at the soaking temperature of $1390^{\circ} \mathrm{C}$. It is inferred that a precipitate of fine crystals of willemite and $\mathrm{ZnO}$ in glass matrix which was resulted by reaction of unsolved $\mathrm{Zn}_{2} \mathrm{SiO}_{4}$ powder excess to its solubility with the flux had scarcely acted as effective nuclei. The willemite crystals were generally colorless and transparent and often contained several columnar cavities and/or flux inclusions. An external shape of the crystal was generally hexagonal prismatic column with $c$-axis orientation, being bounded by $a(11 \overline{2} 0)$ and $r(10 \overline{1} 1)$ faces. Mn-doped willemite crystals were larger than pure ones, the largest having dimensions of $0.5 \times 0.5 \times 6.2 \mathrm{~mm}$. However, they contained more imperfections. When exposed to an ultraviolet light, they fluoresced a light green color.
\end{abstract}

[Received January 13, 1975]

\section{1. 緒言}

Mn を活性化剤として固溶させたウイレマイト $\left(\mathrm{Zn}_{2} \mathrm{SiO}_{4}\right)$ 注蛍光体として知られている。これに, 電子 線または紫外線などを照射すると, 波長 $5250 \AA$ 附近の 緑色の蛍光を発するので, 粉末状のウイレマイトは固体 反応法によって工業的に製造され，蛍光灯および各種の ブラウン管など，すでに実用に供されている ${ }^{1)}$.また， $\mathrm{Li}, \mathrm{Mn}$ などの金属イオンを固溶させると, 抵抗の大き い半導体としての性質を示す ${ }^{2)}$. ウイレマイト単結晶は, 上記の物理的性質を有すると同時に，透明で，熱的に安 定かつ機械的強度が大である。したがって，レーザー素 子その他の光学材料抢よび電子材料としての忘用の研究 を行うのに興味ある物質である. また, 詳細な物理的性 質の測定および結晶構造解析など鉱物学の研究にも有用 であると考えられる。

$\mathrm{Zn}_{2} \mathrm{SiO}_{4}$ は， $\alpha, \beta, \gamma$ の 3 種の変態3) が報告されてい る. 安定形である $\alpha-\mathrm{Zn}_{2} \mathrm{SiO}_{4}$ ウイレマイトは, 融点 $1512^{\circ} \mathrm{C}$ で均一に熔融する. $\beta$ は異極鉱 $\left(\mathrm{Zn}_{4} \mathrm{Si}_{2} \mathrm{O}_{7}(\mathrm{OH})_{2}\right.$ $\left.\cdot \mathrm{H}_{2} \mathrm{O}\right)$ を $700^{\circ} \mathrm{C}$ で熱分解することによって生成する準 安定形で， $960^{\circ} \mathrm{C}$ 以上に加熱すると $\alpha$ に転移する. $r$ は
$\mathrm{Zn}_{2} \mathrm{SiO}_{4}$ 組成の酸化物または塩類の混合物を $500^{\circ} \mathrm{C} に$ 熱した後, 急冷すると生成すると報告されているが，こ れは新しい相か，または $\beta$ の゚リタプであるかは今後 の検討が必要であると考えられている.

ウイレマイトはフェナサイト構造4) を持つ菱面体晶系 で，空間群および格子常数などは， $\mathrm{C}^{2}{ }_{3 \mathrm{i}}=\bar{R} \overline{3}, a_{0}=8.63$ A， $\alpha=107^{\circ} 45^{\prime}, Z=6$ であるが，六方格子をとると， $a_{0}=13.94, \mathrm{C}_{0}=9.309 \AA, Z=18$ である.

ウイレマイトは, 天然では, 米国の New Jersey 州 Franklin の変成岩中などのように限られた地域に, $\mathrm{ZnO}, \mathrm{ZnFe}_{2} \mathrm{O}_{4}$ などと共生して，小針状をたは塊状に集 合して産し, 産出の稀な鉱物である ${ }^{5)}$. 天然産のウイレ マイト結晶は $\mathrm{Mn}, \mathrm{Fe}$ その他多くの不純物を含有する こと，および単結晶の分離は容易でないので, これから 良質の単結晶を得ることは困難であると考えられる。そ こで, 純料で完全性の良い単結晶, または必要な不純物 を必要な量固溶した目的とする単結晶を得るためには, 人工的に単結晶の育成を行う必要がある。また, 珪酸塩 鉣物の単結晶は, 物性測定, 致業などの高温化学の研究 および宝石などとして重要なものがあり，多くの鉣物に 
ついて単結晶成長に関する研究がなされている。 引上法 によるオリビン6), ムライトねな゙，ブリッジマン法では 雲母8 など, フラックス法では, フェナサイト9), エメ ラルド(0)， ウォラストナイト ${ }^{11)}$ なと， 熱水法では，水 晶 $^{12)}$, ジルコン ${ }^{13)}$ など, 多数報告されている.このう ち,フラックス法は, 高温での溶液法であり, 単結晶は, 結晶組成の融点よりかなり低い温度で成長が行われるの で, 高融点の物質, 不均一熔融するものおよび低温変態 の単結晶の成長が可能であるままた，成辰した結晶は， 一般に，自形を持ち，結晶面が良く発達しているので， 鉱物の形態, 物性の研究に有利である.さらに,フラック ス法はマグマからの鉣物結晶の成長の過程と類推的に考 えられ, 天然鉱物の結晶成長の機構の研究もできる. 従 来に执いて, J. Ito ${ }^{14)}$ の珄酸鉛亜鉛の熱分解法, および坂 上ら 2)の水熱合成法によって, 直径 $0.7 \mathrm{~mm}$, 長さ $6 \mathrm{~mm}$ 程度の大きさの単結晶成長が行われている. 著者らは, モリブデン酸ナトリウム执よびタングステン酸ナトリウ ムなどをフラックスとして, 徐泠法によってウイレマイ トの結晶成長を行った. 実験の結果, 直径 $0.36 \mathrm{~mm}$, 長 さ $6.0 \mathrm{~mm}$ 程度の大きさの六角柱状の単結晶を成長さ せることが出来たので報告する。

\section{2. 実 驗 方 法}

フラックス法は融用法とも言われ，この方法によって 単結晶を成長させる方法は，まず，融剤となる塩類など を高温で熔融し，これに目的とする結晶の成分，すなわ ち, 出発物質が飽和するまで溶解させる.つぎに全体を 徐冷して, 溶解度を減少させて単結晶を晶出させる方法 であるから，出発物質の調製，フラックスの適性および 温度プログラムの設定などが重要である.

\section{1 出発物質の調製}

出発物質はつぎのように調製した.すなわち, $1100^{\circ} \mathrm{C}$, 24 時間焼成された試薬特級 $\mathrm{ZnO}$ と $99.5 \%$ 水晶粉末を, ウイレマイトの組成である $\mathrm{ZnO} / \mathrm{SiO}_{2}=2$ (モル比)の割 合で稕量し, ポットミル中で湿式混合した。分散媒には,

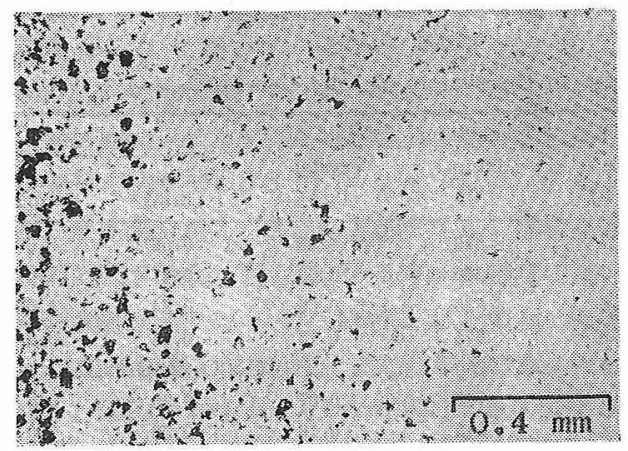

Fig. 1 Microscopic photograph of willemite powder used as starting material for crystal growth.
室温では $\mathrm{ZnO}$ との反忘性がほとんどないと考えられる エタノールを使用した．乾燥後この混合物を白金诗堝中 に入れて電気炉で, $1400^{\circ} \mathrm{C}, 15$ 時間燒成反応至行った。 さらにこれを瑪悩乳鉢で微粉研して結晶成長のための 出発物質とした. X線粉末回折およぴ 図-1 の顕微鏡写 真から, 出発物質は大きさ $10 \mu$ 程度のウイレマイト結 晶粒からなっていることがわかった。その他， $\mathrm{ZnO}$ と $\mathrm{SiO}_{2}$ の混合物および $\mathrm{ZnO} / \mathrm{Zn}_{2} \mathrm{SiO}_{4}=4$ の混合物の出発 物質についても結晶成長の実験を行った。

\section{2 フラックスの選定}

フラックスとしての条件は, 高温において結晶組成と 反応して安定な化合物を作らないが，他方，これを良く 溶解するこどである.また, 結晶中に有害な不純物の固 溶の原因とならぬいるのであって，さらに，成長した目 的の結晶との分離が容易でなければならない。一般に， フラックスとしては，低融点の金属酸化物または塩類な どが使用されている、本実験では，フラックスとして， $\mathrm{Li} ， \mathrm{Na}$ ，K などの塩化物，モリブデン酸塩およびタン グステン酸塩などが検討された. 結果, ウイレマイト単 結晶成長のためのフラックスは, $\mathrm{Na}_{2} \mathrm{MoO}_{4}$ が最もよく, 次いで $\mathrm{Na}_{2} \mathrm{WO}_{4}$ であることが分かった. そこで, 主に $\mathrm{Na}_{2} \mathrm{MoO}_{4}$ をフラックスとして選定した.

\section{3 結晶成長方法}

78〜103 g のフラックスにたいして，出発物質を 2.4 $\sim 5.5 \mathrm{~g}$ 混合する.これを $50 \mathrm{cc}$ 蓋付白金坩堝中に入れ て, 四-2(a) に示す電気炉を使用して, 空気中で加熱し た. 加熱は, まず, $1215 \sim 1405^{\circ} \mathrm{C}$ の間の範囲における 所定の最高温度まで $4 \sim 6$ 時間かかっって加熱された。っ
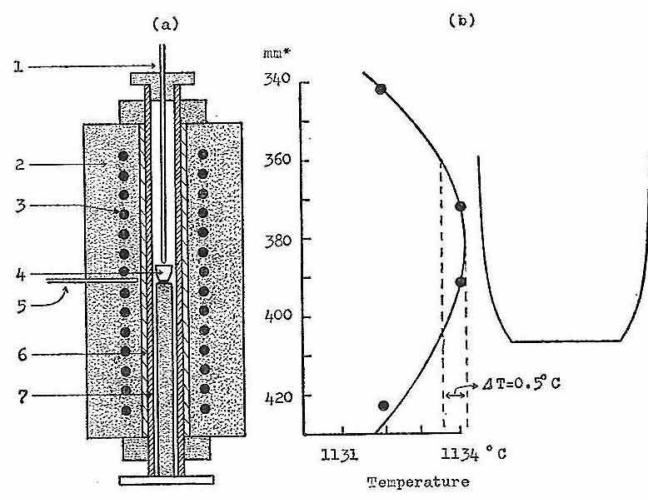

*Distance from upper end of furnace.
1. Thermocouple for reading.
2. Refractory.
3. SiC resistant.
4. Crucible with sample.
5. Thermocouple for control.
6. Chamotte tube.
7. Mullite tube.

Fig. 2 Schematic arrangement (a) and temperature distribution (b) of electric furnace. 


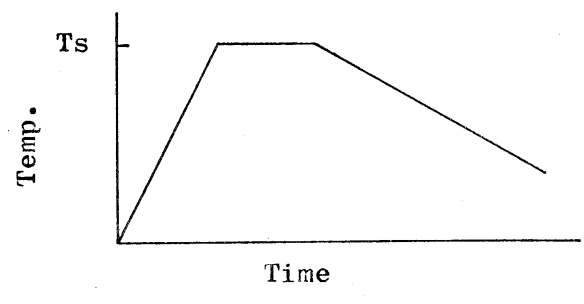

$T s$ : Soaking temperature

Fig. 3 Schematic temperature program for crystal growth by flux method.

ぎに，その温度で $3 \sim 15$ 時間の範囲の所定時間，一定 温度に保持した後, $3.3 \sim 5.7^{\circ} \mathrm{C} / \mathrm{h}$ の降温速度で約 $800^{\circ} \mathrm{C}$ まで徐冷した. 図-3 に加熱の温度プログラムを図示す る. 以上の操作によって結晶成長が行われた.なお，こ の間の坩堝附近の温度勾配 (図-2(b)) 拉よび温度変動は $\pm 2^{\circ} \mathrm{C}$ 以内保った. 冷却後, 水によって試料中のフラ ックスを溶解除去して結晶の分離を行った．得られた結 晶について，顕微鏡観察およびX線回折などを行った。

\subsection{X線回折法}

粉末法の場合は, 理学電機製ローターフレックス $\mathrm{RU}$ -200 PL 自記X線回折装置を使用した。測定条件は, $\mathrm{Cu} \mathrm{K} \alpha, 45 \mathrm{kV}, 120 \mathrm{~mA}$, 時定数 1, scanning speed は $1 \%$ min，および精密測定は内部標準として Si を使用し て scanning speed $1 / 8 \%$ min とした. 単結晶法によ る振動写真およびワイセンベルグ写真は理学電機製ワイ センベルグカメラを使用した.

\section{5 結晶面角測定}

結晶の面角測定には，Stoe \& Cie 社製ゴールドシュ ミット型複円反射測角器を使用した.

\section{3. 結 果}

\section{1 結晶の成長}

$\mathrm{Zn}_{2} \mathrm{SiO}_{4}$ の出発物質と 2.2 項で述べたフラックスに ついて実験の結果, $\mathrm{LiCl}, \mathrm{Li}_{2} \mathrm{MoO}_{4}$ および $\mathrm{Li}_{2} \mathrm{WO}_{4}$ な ぞ $\mathrm{Li}$ を含むフラックスからは，大きさ $2 \mathrm{~mm}$ 程度の $\mathrm{Li}_{2} \mathrm{ZnSiO}_{4}$ 結晶が成長した ${ }^{15)} \cdot \mathrm{NaCl}$ フラックスからは

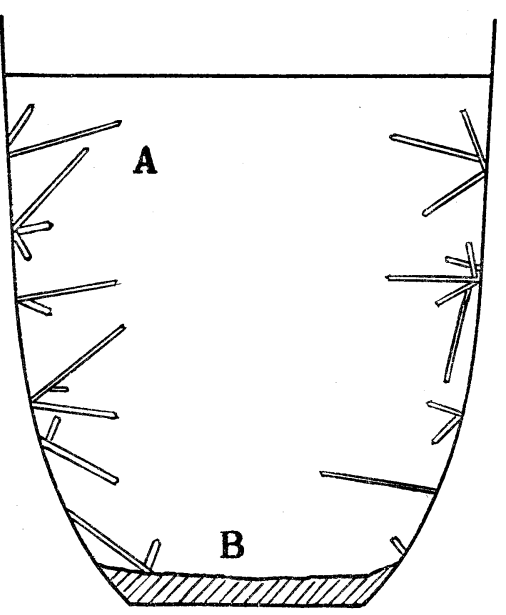

A : Needle-shaped willemite crystals.

B : Unsolved residue excess to its solubility.

Fig. 4 Schematic arrangement of the grown crystals in the Pt crucible.

直径 $0.1 \mathrm{~mm}$, 長さ $3 \mathrm{~mm} の \mathrm{Na}_{2} \mathrm{O} \cdot 2 \mathrm{ZnO} \cdot 2 \mathrm{SiO}_{2}$ 結晶が 成長した. $\mathrm{KCl}, \mathrm{K}_{2} \mathrm{MoO}_{4}$ および $\mathrm{K}_{2} \mathrm{WO}_{4}$ フラックスか らは沈港物のみ生成した. $\mathrm{Na}_{2} \mathrm{MoO}_{4}$ と $\mathrm{Na}_{2} \mathrm{WO}_{4}$ フラ ックスから, ウイレマイト単結晶は, 坩堝の壁より中心 に向って，自然発生の核から針状結晶として成長した。 図-4 の模式図に示す. また，出発物質は過鄱に加えて あるので，未溶解の部分は烓垢の底に沈溉物となって固 結した。

以上の結果，ウイレマイト単結晶成長のためのフラッ クスは, $\mathrm{Na}_{2} \mathrm{MoO}_{4}$ が適当であると考えられた. そこで， 2.1 項で述べた出発物質にたいして, $\mathrm{Na}_{2} \mathrm{MoO}_{4}$ をフラ ックスとして最高温度を変えて実験を行った結果を表-1 に総括する.この表で, 結晶の大きさとは, 各実験にお いて得られた多数の結晶のうち，大きいものから 2 3 個選んで平均したものである.成長したウイレマイト単 結晶の大きさ，すなわち，結晶の長さおよび直径，さ らに結晶の収量について, 最高温度との関係を 図-5 に 表わす. 図-6 の写真は，最高温度が 1215, 1330, 1375,

Table 1 Summary of crystal growth of willemite in the system $Z_{2} \mathrm{SiO}_{4}-\mathrm{Na}_{2} \mathrm{MoO}_{4}$.

\begin{tabular}{|c|c|c|c|c|c|c|c|c|c|}
\hline \multirow{2}{*}{$\begin{array}{l}\text { Run } \\
\text { No. }\end{array}$} & \multicolumn{2}{|c|}{ Composition } & \multicolumn{2}{|c|}{ Soaking } & \multirow{2}{*}{$\begin{array}{l}\text { Cooling } \\
\text { rate } \\
\left({ }^{\circ} \mathrm{C} / \mathrm{h}\right)\end{array}$} & \multirow{2}{*}{$\begin{array}{c}\text { Quenching } \\
\text { temp. } \\
\left({ }^{\circ} \mathrm{C}\right)\end{array}$} & \multirow{2}{*}{$\begin{array}{l}\text { Yield of } \\
\text { crystal } \\
(\mathrm{g})\end{array}$} & \multicolumn{2}{|c|}{ Crystal size } \\
\hline & $\begin{array}{c}\mathrm{Na}_{2} \mathrm{MoO}_{4} \\
(\mathrm{~g})\end{array}$ & $\begin{array}{c}\mathrm{Zn}_{2} \mathrm{SiO}_{4} \\
(\mathrm{~g})\end{array}$ & $\begin{array}{c}\text { Temp. } \\
\left.\text { ( }{ }^{\circ} \mathrm{C}\right)\end{array}$ & $\underset{\text { (h) }}{\text { Time }}$ & & & & $\underset{(\mathrm{mm})}{\text { Diameter }}$ & $\begin{array}{l}\text { Length } \\
(\mathrm{mm})\end{array}$ \\
\hline G2-17 & 96.7 & 3.0 & 1215 & 14.5 & 5.7 & 870 & 0.03 & 0.05 & 3.3 \\
\hline $\mathrm{G}_{2}-16$ & 97.1 & 3.0 & 1290 & 15.0 & 5.3 & 800 & 0.06 & 0.17 & 5.0 \\
\hline G2- 3 & 102.8 & $2.8^{+}$ & 1330 & 14.0 & 3.3 & 835 & 0.06 & 0.34 & 4.0 \\
\hline $\mathrm{G}_{2}-4$ & 94.4 & $5.5^{+*}$ & 1330 & 4.0 & 3.9 & 875 & 0.14 & 0.34 & 6.2 \\
\hline $\mathrm{G}_{2-21}$ & 78.7 & $2.4^{* *}$ & 1360 & 15.0 & 4.8 & 880 & \multicolumn{3}{|c|}{$\left(\mathrm{Na}_{2} \mathrm{O} \cdot 2 \mathrm{ZnO} \cdot 2 \mathrm{SiO}_{2}\right)$} \\
\hline $\mathrm{G}_{2-19}$ & 77.9 & 3.0 & 1375 & 9.5 & 4.8 & 700 & 0.07 & 0.28 & 5.8 \\
\hline $\mathrm{G}_{2-20}$ & 79.0 & 3.0 & 1390 & 12.0 & 5.2 & 840 & 0.16 & 0.36 & 6.0 \\
\hline G2-15 & 93.9 & 3.5 & 1405 & 3.0 & 4.8 & 870 & 0.15 & 0.36 & 3.5 \\
\hline
\end{tabular}

+Mixture of $\mathrm{ZnO}$ and $\mathrm{SiO}_{2}$ with molar ratio of $2: 1$.

$* \mathrm{MnO}_{2}$ of $0.3 \mathrm{~g}$ added.

$* * \mathrm{ZnO}$ of $1.6 \mathrm{~g}$ added. 


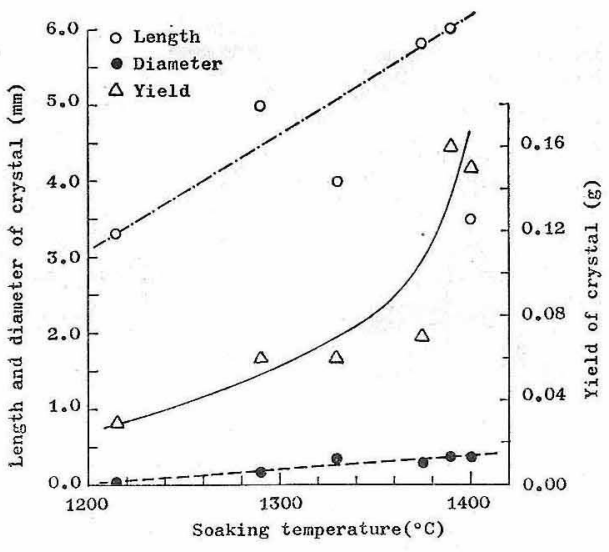

Fig. 5 Yield and size of willemite crystal vs. soaking temperature.

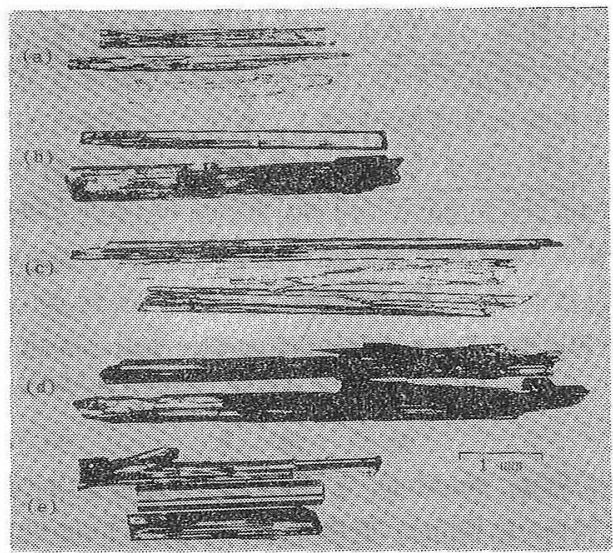

Fig. 6 Willemite single crystals grown at the soaking temperatures of (a)1215, (b) 1330 , (c) 1375 , (d) 1390 and (e) $1405^{\circ} \mathrm{C}$ from $\mathrm{Na}_{2} \mathrm{MoO}_{4}$ flux.

1390 および $1405^{\circ} \mathrm{C}$ の場合得られた単結晶である. 表一 1 と図 5 6 からら明らか子ように, 成長結晶は著しく最 高温度の影響をうけた。すなわち, (1)出発物質はウイレ マイトの組成であれば，実験 G2-3 4 の酸化物の混合 物と，焼成反応物の場合とでは差は認められない。しか し, 実験 $\mathrm{G} 2-21$ に执いて, $\mathrm{ZnO}$ を過剩称ると直径 $0.26 \mathrm{~mm}$, 長さ $4.0 \mathrm{~mm}$ の $\mathrm{Na}_{2} \mathrm{O} \cdot 2 \mathrm{ZnO} \cdot 2 \mathrm{SiO}_{2}$ の結晶 が得られ，ウイレマイト結晶は成長しない。(2)結晶の収 量法，最高温度が $1215^{\circ} \mathrm{C}$ で $0.03 \mathrm{~g}, 1405^{\circ} \mathrm{C}$ で $0.15 \mathrm{~g}$ となり，最高温度が高くなるほど増大する。(3)最高温度 が $1290^{\circ} \mathrm{C}$ 以下では，長さ $3.3 \sim 5.0 \mathrm{~mm}$ 程度の細、針 状と薄板状単結晶であるが， $1330^{\circ} \mathrm{C}$ 以上の高い温度に なると，大きく成長し，六角柱状または厚みのある板状結 晶となる. $1390^{\circ} \mathrm{C}$ のとき，大きい結晶は，長さが $6 \mathrm{~mm}$, 直径 $0.36 \mathrm{~mm}$ まで成長した. (4)結晶の完全性と大きさ から考えて, 最高温度は $1390^{\circ} \mathrm{C}$ 附近のときが最も良好 であった、Mn をドープした場合は，比較的大きな単結
晶が成長するが，結晶中に空孔が発生しやすくなり，結 晶の品質が悪くなる傾向にある。

\section{2 成長結晶の観察}

\subsection{1 ウイレマイト単綰晶の結晶形}

成長したウイレマイト単結晶の結晶面のステレオ投影 図を図-7に示す。この図より, 観察された主な結晶面 上面角は， $a(11 \overline{2} 0) \wedge r(10 \overline{1} 1)=58.5^{\circ}$ であった。これは 面角の計算值が $58.1^{\circ}$ であること加らも確められる。 結晶の外形は, 六角柱状形を基本とするものが大部分で ある.図-8 の写真と模式図に示す。

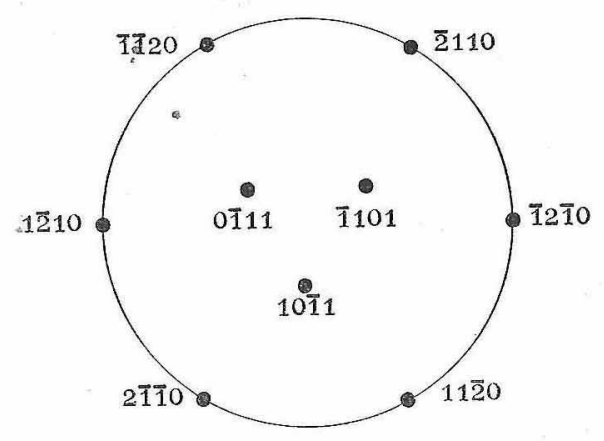

Fig. 7 Stereographic projection of the grown willemite crystal.

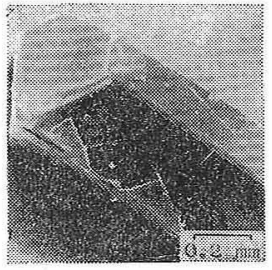

(a)

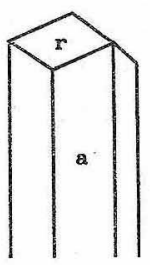

(b)
Fig. 8 Photograph (a) and schematic illustration (b) of the willemite crystal, showing $a$ (11̄20) and $r(10 \overline{1} 1)$ faces.

\section{2 .2 单結晶中の空孔}

良質で透明な結晶も存在するが，多くの場合，結晶の 久楩構造として空孔が存在する。最も普通に出現する空 孔忙，針状結晶の中心部に执いて，一本または数本存在 し，結晶の伸長方向すなわち $c$ 軸方向に平行に長く伸び ている. 図-9 (a) に示す, 直径 $0.1 \sim 0.35 \mathrm{~mm}$ 程度の 結晶にたいして，空孔の直径は $10 \sim 100 \mu$ 程度で，かな り大きいものも㐬孔、空孔何も入っていない場合と， フラックスの包有物を含有した場合がある。これらの空 孔の断面は不規則なものも存在するが，図-9(b) に示さ れるように，結晶の外形と同じ六角柱状形で，いわいる negative crystal と考允らるるのもある.この種の空 孔は，一般に最高温度が高く，大きい六角柱状単結晶に 成長したとき出現しやすい。 


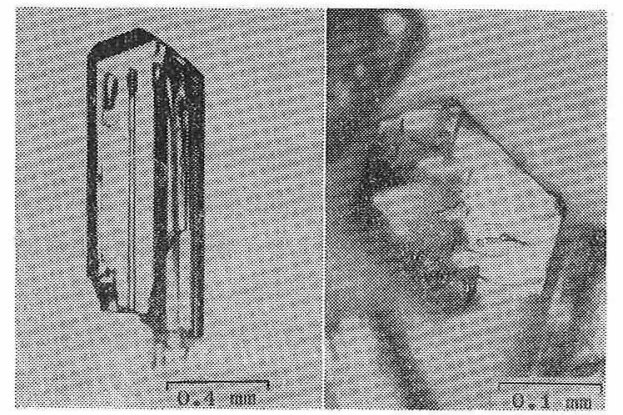

(a)

(b)

Fig. 9 Willemite crystal containing columnar cavities (a) and cross section of hollow hexagonal prism (b).

\section{3 螢光体ウイレマイト策結晶の成長}

結晶成長に先立っ $て$, 出発物質中に, 固相反応法によ って約 $5 \%$ の Mn 固溶させておく々，Mn を固溶し を淡い紫挑色を呈する結晶が成長した。この結晶は紫外 線照射によって，鮮明な緑色の蛍光発発光した。図-10 の写真に示す。

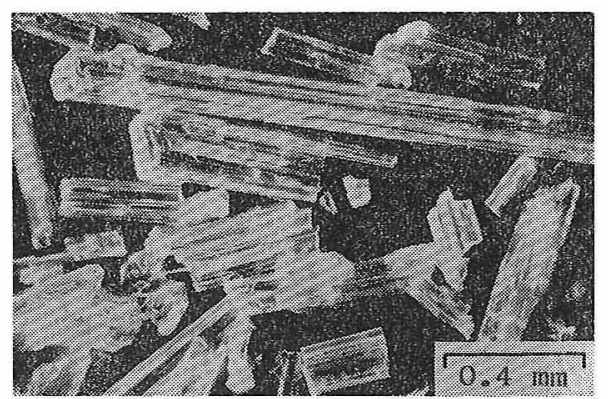

Fig. $10 \mathrm{Mn}$-doped willemite crystals fluorescing a light green color when they were exposed to an ultraviolet light.

\subsection{X線回折の結果}

X線粉末回折図, 振動写真およびワイセンベルグ写真 の結果, フラックスから成長した単結晶の空間群, 格子 常数恃， $\mathrm{C}_{3 \mathrm{i}}=R \overrightarrow{3}$ ，六方格子をとると $a_{0}=13.94, C_{0}=$ $9.309 \AA$ であり,これらはウイレマイトの文献值 ${ }^{4)}$ と一 致した。灾た，空孔などの知陷の多い結晶粒も X線的に は単結晶であった。測定の範围内では双晶結晶は観察さ れなかった.Mnを固溶したウイレマイトは， $a_{0}=13.94$ $\AA, c_{0}=9.311 \AA$ でわずかな $c$ 軸の増加があった。

\section{4. 考 察}

フラックスにたいする溶解度より過剩に加えたことに よる未溶解の出発物質, 叔よび反忘生成物は坩堝の底に 固結した沈溊物となって存在することはすでに述べた。 実験 G2-20 の沈澱物についてとった，クロスニコル偏 光顕微鏡写真亡 $\mathrm{X}$ 線粉末回折図を図 11 12 に示す.こ

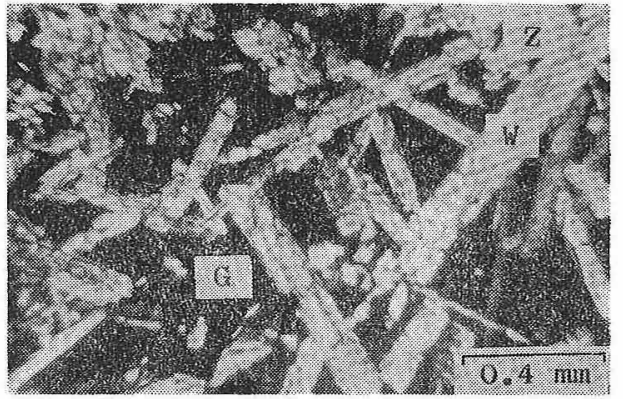

$\mathrm{W}$ : willemite, $\mathbf{Z}: \mathrm{ZnO}, \mathrm{G}$ : glass matrix

Fig. 11 Microscopic photograph of precipitates between crossed nicols showing willemite and $\mathrm{ZnO}$ crystals in glass matrix.

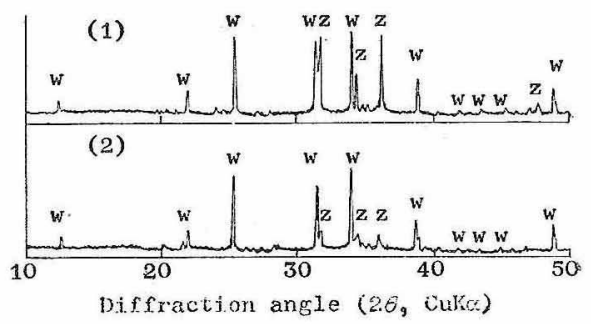

$\mathrm{W}:$ willemite, $\mathrm{Z}: \mathrm{ZnO}$

Fig. $12 \mathrm{X}$-ray diffraction powder patterns of precipitates prepared from $\mathrm{Na}_{2} \mathrm{MoO}_{4}$ (1) and $\mathrm{Na}_{2} \mathrm{WO}_{4}$ (2) fluxes.

れらの結果, $\mathrm{Na}_{2} \mathrm{MoO}_{4}$ と $\mathrm{Na}_{2} \mathrm{WO}_{4}$ フラックスの場合 の沈澱物の結晶相は, 直径 $0.1 \mathrm{~mm}$, 長さ $1 \mathrm{~mm}$ 程度の ウイレマイトと $0.05 \mathrm{~mm}$ 程度の $\mathrm{ZnO}$ で，これらをと り困んでガラスマトリックスが生成していた.このこと は, フラックス中への $\mathrm{Zn}_{2} \mathrm{SiO}_{4}$ の溶解析出反応の外に, フラックスと $\mathrm{Zn}_{2} \mathrm{SiO}_{4}$ 沈澱物の一部分が，つぎの (1) と（2）式で表わされるように反応するものと推定され， る.

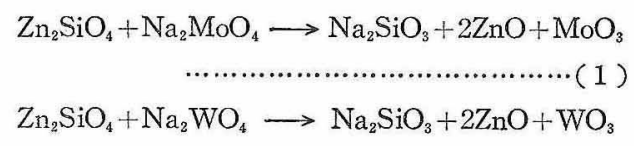

（1）または (2) 式で生成する $\mathrm{Na}_{2} \mathrm{SiO}_{3}$ は，さらに $\mathrm{ZnO}$ や $\mathrm{Zn}_{2} \mathrm{SiO}_{4}$ などと反応して, $\mathrm{Na}_{2} \mathrm{O}-\mathrm{ZnO}-\mathrm{SiO}_{2}$ 系ガラ ス㕶生成するものと推定される。このがラスの生成は, ウイレマイトの結晶成長に大きな影響を与兄るものと考 えられるので，つぎに最高温度が， $1400^{\circ} \mathrm{C}$ 上下の場合 にわけて考察する.

\section{1 最高温度が $1490^{\circ} \mathrm{C}$ 以下の場合}

最高温度に抒いて，その初期段階は，まず，結晶成分 はフラックス中ー溶解しフラックスは飽和溶液となる。 次いで, 坩堝の底の沈澱物である未溶解の結晶成分の一 部分がフラックスと反応してガラスが生成する.そして 
微小結晶よりなっている沈澱物はこのガラス層によって 覆われる．この状態は徐冷による結晶成長過程で, 結晶 核とはならない。したがって，結晶は坦堝の壁の自然発 生の比較的少数の核からのみ成長がおこり, 結晶は大き く成長する.すなわち, 出発物質が過剩であってもこれ は結晶核の生成には関倸が少ないので，成長 結 晶の大 小，収量の多少に与える影響は少ないものと考えられ る.したがって, $1400^{\circ} \mathrm{C}$ 以下の最高温度の範囲では, 最 高温度が高いなど，溶解度が大となり，良好な結晶成長 条件となるものと考えられる。

\section{2 最高温度が $1400^{\circ} \mathrm{C}$ 以上の場合}

最高温度が $1400^{\circ} \mathrm{C}$ 以上になると，ガラス生成反応が 著しくなり，フラックス中への結晶成分の溶解反応が完 了する前に, 出発物質の表面がガラスによって覆われて しまい，溶解が十分行われない.さらに徐冷にさいして 結晶が析出しても, $1400^{\circ} \mathrm{C}$ 附近までは, 高温のためガ ラスとなり易く，結晶の収量は減少するものと考えられ る.したがって,このガラス生成反応速度が, 結晶成長の ための最高温度の上限を決定するものと考えられる．以 上述べた現象は，珪酸塩化合物の単結晶成長においては 常に考慮する必要があろう・実験結果およびこの考察か ら， $\mathrm{Na}_{2} \mathrm{MoO}_{4}$ フラックスからのウイレマイト結晶成長 は， $1390^{\circ} \mathrm{C}$ 附近の最高温度が適当であると考えられる.

\section{4. 総 括}

フラックス徐冷法によって, ウイレマイトの単結晶成 長実験を行って，つぎの結果が得られた。

(1) フラックスとして検討された， $\mathrm{Li}, \mathrm{Na}, \mathrm{K}$ など の塩化物, モリブデン酸塩およびタングステン酸塩のう ち, $\mathrm{Na}_{2} \mathrm{MoO}_{4}$ と $\mathrm{Na}_{2} \mathrm{WO}_{4}$ フラックスから単結晶が成 長した. $\mathrm{Na}_{2} \mathrm{MoO}_{4}$ が適当であったので，以後，フラッ クスとしてこれを使用した．出発物質は，合成ウイレマ イト粉末を使用した.この場合，ウイレマイト組成の $\mathrm{ZnO}$ と $\mathrm{SiO}_{2}$ の混合物でもよい.

(2) $1215 \sim 1405^{\circ} \mathrm{C}$ の実験範囲の最高温度で単結晶
は成長したが, $1390^{\circ} \mathrm{C}$ 附近が適当で, 結晶の収量は $0.16 \mathrm{~g}$ であった. 単結晶は直径 $0.36 \mathrm{~mm}$, 長さ $6.0 \mathrm{~mm}$ 程度の $c$ 軸方向に伸びた針状結晶である. 徐冷速度は $3.3 \sim 5.7^{\circ} \mathrm{C} / \mathrm{h}$ の範囲で, 約 $800^{\circ} \mathrm{C}$ まで結晶成長を行っ た.

（3）フラックスにたいする溶解度より過剩に加えた ことによる未溶解の出発物質は，少量のガラスとともに 坩堝の底に固結し, 単結晶は主として坩堝壁の自然発生 の核から成長した。

（4）良質の結晶の外に，内部に欠宿構造として空孔 が存在する結晶，および骸晶状結晶が成長した。これ は, 結晶が $c$ 軸方向のみ速く成長した結果と推定され る.

\section{文献}

1) 日本化学会編, “化学便覽 応用編” 丸善 (1965) p. 275 $-81$.

2）坂上登，長谷川修三，広田慎一郎，和田正信，第 14 回人 工鉱物討論会講演要旨集 (1969) p. 92-93.

3) H.F.W. Taylor, Am. Mineral. 47, 932-44 (1962).

4) W.L. Bragg and W.H. Zachariasen, Zeit. Krist. 72, 518 (1930).

5) E.S. Dana and W.E. Ford, "A Textbook of Mineralogy" John Willey \& Sons, Inc. (1962) p. 601.

6) H. Takei and T. Kobayashi, J. Crystal Growth 23, 121-24 (1974).

7) W. Guse and D. Mateika, J. Crystal Growth 22, 237-40 (1974).

8）松下徹, “新しい工業材料の化学 B-11”, 永井彰一郎編, 金原出版 (1968) p. 39-57.

9）進藤勇，小松啓，児島弘直，第 19 回人工鉱物討論会講演 要旨集 (1974) p. 85-86.

10) E.M. Flanigen, D.W. Breck, N.R. Mumbach and A.M. Taylor, Am. Mineral. 52, 744-72 (1967).

11）瀬戸口正宏, 坂本千秋, 窐協 75, 325-29 (1967).

12）滝貞男, 窯協 71, C 157-62 (1963).

13) R. Uhrin, R.F. Belt and R.C. Puttbach, J. Crystal Growth 21, 65-68 (1974).

14) J. Ito, Am. Mineral. 53, 231-40 (1968).

15) M. Setoguchi and C. Sakamoto, J.Crystal Growth, 24/25, 674-76 (1974).

(1/13/1975 受付) 